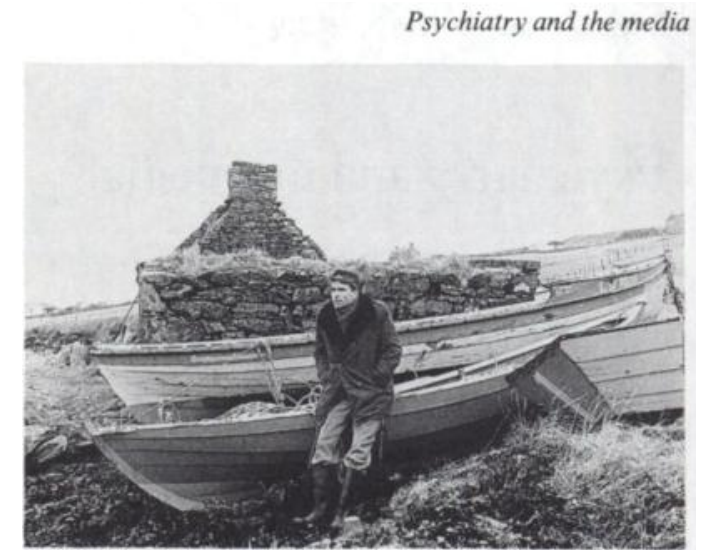

35 Up: Neil. Copyright Granada Television.

and through him the programme uncovered one type of disadvantage which shows no sign of changing.

\title{
Miscellany
}

\section{John Young Memorial Fund}

The Reverend Dr John Young was a pioneering consultant psychiatrist in the field of old age psychiatry. He died on 5 February 1991. (See Obituary, Psychiatric Bulletin, July 1991, 15, 459-460.) The members of the West Midlands Association of Psychogeriatricians have decided to institute a fund in memory of his name and to award an annual prize out of the proceeds. It would be in the form of an essay competition for SHOs and registrars training in old age psychiatry in the West Midlands Region. There is now an appeal for donations. Cheques may be drawn in favour of "John Young Memorial Fund" and forwarded to Dr D. Gaspar, Convenor, John Young Memorial Fund, Postgraduate Clinical Tutor in Old Age Psychiatry, West Midlands Region, Hollymoor Hospital, Birmingham B31 5EX.

\section{Rehabilitation for torture victims}

The International Rehabilitation Council for Torture Victims (IRCT) is an independent non-profit making foundation which was created in 1985 by the Rehabilitation and Research Centre for Torture Victims (RCT) Copenhagen. Its objectives include the accumulation and dissemination of information about torture, the consequences of torture and the possibilities of rehabilitating people who have been tortured; the support of international and national initiatives, organisations and agencies concerned with torture; the support of research into all aspects of torture, and serving as an international clearing house for information about activities within the scope of IRCT objectives. Further information: IRCT, Juliane Maries Vej 34, PO Box 2672, DK-2100 Copenhagen $\varnothing$, Denmark.

\section{Mentally incapacitated adults and decision-making}

The Law Commission Consultation Paper No. 199, Mentally Incapacitated Adults and Decision-Making: An Overview was issued on 30 April 1991 and is published by HMSO, price $\mathbf{6 6 . 9 0}$. Copies of the response to Consultation Paper No. 119 by the Law Society's Mental Health Sub-Committee are available from Shirley Holloway, The Law Society, 50 Chancery Lane, London WC2A 1SX (please send A4 SAE).

\section{Appointment}

Professor R. E. Kendell has been appointed Chief Medical Officer for Scotland.

\section{New organisation}

A new organisation will be formed when the Medical Campaign against Nuclear Weapons merges with the Medical Association for Prevention of War next year. Its aim will be to create a channel to enable health professionals to extend their concerns beyond prevention of war to helping foster new concepts of health and global security. Further information: Medical Campaign against Nuclear Weapons, 601 Holloway Road, London N19 4DJ. 